\title{
Natural and induced ovulation rate in prolific and non-prolific breeds of sheep in Ireland, Morocco and New Zealand
}

\author{
J. F. Quirke*\|, H. H. Meyer†\#, A. Lahlou-Kassi $\ddagger$ J. P. Hanrahan*, \\ G. E. Bradford $\S$ and G. H. Stabenfeldt $\S$
}

*The Agricultural Institute, Belclare, Tuam, Co. Galway, Ireland; †Ministry of Agriculture and Fisheries, Ruakura Animal Research Centre, Private Bag, Hamilton, New Zealand; $\ddagger$ Department of Reproduction and Artificial Insemination, Institut Agronomique et Veterinaire Hassan 11, AgdalRabat, Morocco; and §Departments of Animal Science and of Reproduction, School of Veterinary Medicine, University of California, Davis, California 95616, U.S.A.

\begin{abstract}
Summary. Ovulation rate, in mixed-age groups of prolific and non-prolific ewe breed types, after administration of a range of doses of PMSG (0, 375, 750 and 1500 i.u.) during the follicular phase of the oestrous cycle, were compared in Ireland, Morocco and New Zealand. The ewes in Ireland and Morocco were from the Finnish Landrace and Galway, and D'Man and Timhadite breeds, respectively. In New Zealand Booroola Merino $\times$ Romney ewes which had been previously identified as heterozygous carriers $(\mathrm{F}+)$ of the Booroola high fecundity gene and purebred Romneys were used to represent the prolific and non-prolific genotypes respectively; in addition a group of Booroola Merino $\times$ Romney non-carriers $(++)$ of the major gene were also included for comparison. Ovulation rate at the oestrus which preceded stimulation with PMSG was also measured in all animals.

In all 3 locations the ewes of the prolific genotype had a greater ovulation rate after PMSG stimulation than did the non-prolific controls. However, this association between prolificacy and response to PMSG was removed when ovulation rate after PMSG was transformed by dividing by the ovulation rate observed before PMSG administration. Despite the differences in the genetic basis of their high prolificacy the pattern of response to PMSG over the range of dosages used was similar in Finnish Landrace, D'Man and Booroola Merino $\times$ Romney $(F+)$ ewes and all breeds had means of about 10 ovulations in response to 1500 i.u. PMSG. Amongst the non-prolific breeds, the Timhadite was the most responsive to PMSG although it had the lowest natural ovulation rate.

Information on fertility and litter size was available for all breeds in Ireland and New Zealand. In all breeds fertility was depressed at the highest dose of PMSG. Litter size at birth increased in all non-prolific breeds as the dose of PMSG was raised. For the prolific breeds, increasing the dose of PMSG from 750 to 1500 i.u. resulted in a substantial reduction in the number of lambs born.
\end{abstract}

\section{Introduction}

The physiological basis for variation in ovulation rate in sheep has been the subject of numerous studies during the past decade. Typically, in these studies, the endocrine profile for a prolific breed

„Present address: Boehringer Ingelheim Vetmedica, 6507 Ingelheim am Rhein, West Germany.

\#Present address: Department of Animal Science, Oregon State University, Corvalis, Oregon 97331, U.S.A. 
is compared with that of a local low fecundity breed type. The high fecundity breeds which have received most attention are the Finnish Landrace (Finn), Romanov, Booroola Merino and more recently the D'Man. These breeds, however, are scattered in widely different geographical locations and have not been subjected to the same intensity of scientific investigation.

Recent research results have shown that the high ovulation rate of the Booroola Merino can be attributed to the action of a single gene (Piper \& Bindon, 1982). The available evidence for the Finn and Romanov, on the other hand, suggests that ovulation rate and prolificacy can be considered as traits which are under polygenic control. There is as yet no evidence concerning the nature of the genetic basis for the high fecundity of D'Man sheep.

Direct measurement of pituitary gonadotrophins and ovarian steroids in the peri-ovulatory periods and comparison with appropriate low fecundity breeds have not consistently explained the high ovulation rates of the Finn, Romanov and Booroola Merino breeds (Land et al., 1973; Bindon et al., 1979, 1984; Quirke et al., 1979; Cahill et al., 1981). However, comparisons of the D'Man and Booroola Merino with appropriate low fecundity breeds, (Lahlou-Kassi et al., 1984; Bindon et al., 1985 ) indicate a positive association between ovulation rate and the concentration of FSH in the peripheral plasma in the preovulatory period.

The ovarian response to exogenous gonadotrophin can also provide a useful indirect measure of the endocrine differences between genetic groups. Lines of high fecundity Merino and Romney ewes have been found to be more sensitive to pregnant mares' serum gonadotrophin (PMSG) than are low fecundity controls (Bindon et al., 1971; Smith, 1976). This is also true for the Booroola Merino (Bindon \& Piper, 1982) but does not appear to be so for Finnish Landrace ewes, the ovulation rate of which has been changed as a result of genetic selection (Hanrahan \& Quirke, 1982). The ovarian responses to graded doses of PMSG of the various breed types which are recognised to be highly prolific have not been compared. A comprehensive comparison of these breeds in the same location is unlikely in the near future because of their wide geographical dispersion. This report deals with the results of a collaborative experiment between researchers in Ireland, Morocco and New Zealand working with Finnish Landrace, D'Man, and Booroola Merino $\times$ Romney ewes, respectively. Ovarian response to a range of doses of PMSG from the same batch was examined by using the same experimental protocol at each location. The responses of ewes of each prolific breed were compared with those of a local non-prolific breed.

\section{Materials and Methods}

The high and low prolificacy breed types evaluated at each location and the number of ewes assigned to each dose of PMSG are given in Table 1. Ewes from each of the age classes of $1 \cdot 5,2 \cdot 5$ and $\geq 3.5$ years old were allocated at random to the different doses of PMSG. The F1 Booroola $\times$ Romney ewes had been classified on the basis of previous ovulation rates as non-carriers $(++)$ or heterozygous carriers $(\mathbf{F}+)$ of the Booroola high fecundity gene according to the nomenclature and criteria suggested by Davis et al. (1982). All ewes were treated with vaginal sponges containing $40 \mathrm{mg}$ cronolone (Chrono-gest, Intervet S.A., Angers Cedex, France) for 14 days beginning on 8 October, 15 October, 1982, and $3 \mathrm{March}, 1983$ in Ireland, Morocco and New Zealand respectively. Vasectomized rams, painted on the brisket or wearing a marking harness, were placed with the ewes after sponge removal and the incidence of oestrus was established by checking daily for evidence of mating. The ewes were also weighed close to this time. On the 15 th day after sponge removal each ewe was injected intramuscularly with $0,375,750$ or 1500 i.u. PMSG in $1 \mathrm{ml}$ sterile water. The PMSG used at each location was from the same batch of manufacture (kindly provided by D. Aguer, Intervet S.A., Angers Cedex, France). After injection of PMSG the ewes were placed with rams of their own breed (1 $\mathrm{ram} / 10$ ewes) and inspected twice daily thereafter to determine the time of onset of the second oestrus after sponge removal. Intact rams were used in Ireland and New Zealand but vasectomized rams were used in Morocco. Ovulation rate at both oestrous periods was assessed by endoscopy.

A blood sample, for progesterone determination, was collected from all ewes in Ireland and New Zealand by jugular venepuncture 8-12 days after onset of the oestrus following PMSG (mainly on Day 10). After preparation all plasma samples were frozen and stored at $-20^{\circ} \mathrm{C}$ until they were transported from their country of origin to the University of California, Davis, for assay. Progesterone concentrations were determined using an enzymeimmunoassay which has been described in detail elsewhere (Munro \& Stabenfeldt, 1984). The inter- and intra-assay coefficients of variation for pools of high, medium and low progesterone concentrations were $4 \cdot 9,6 \cdot 2,10 \cdot 5$ and $8 \cdot 7,10 \cdot 9$, $14 \cdot 5$, respectively. The sensitivity of the assay was $5 \mathrm{pg} / \mathrm{ml}$ using $40 \mu \mathrm{l}$ plasma. 
Table 1. Breeds used and age structure of the samples of ewes at each location

\begin{tabular}{lccc}
\hline & \multicolumn{3}{c}{ No. of ewes } \\
\cline { 2 - 4 } Location and breed & $1 \cdot 5$ years & $2 \cdot 5$ years & $\geq 3$ years \\
\hline Ireland & 18 & 21 & 20 \\
$\quad$ Galway & 18 & 29 & 13 \\
$\quad$ Finnish Landrace & & & \\
Morocco & 20 & 20 & 19 \\
$\quad$ Timhadite & 20 & 18 & 20 \\
$\quad$ D'Man & & & \\
New Zealand & 19 & 19 & 20 \\
$\quad$ Romney & 18 & 20 & 20 \\
$\quad$ Booroola $\times$ Romney $(++)$ & 19 & 20 & 19 \\
$\quad$ Booroola $\times$ Romney $(\mathbf{F}+)$ & 19 \\
\hline
\end{tabular}

The data from each country were analysed separately using least squares procedures and models which included breed type, age and dose of PMSG as main effects and the two factor interactions. Preliminary examination of ovulation rate following PMSG showed that variation within breed $x$ dose subclasses increased with the mean. Plots of the within-subclass standard deviation against mean ovulation rate showed that logarithmic transformation removed this association. For this trait therefore the data were analysed after logarithmic transformation. To explore the generality of the differences between prolific and non-prolific breeds in their response to PMSG an analysis involving data from all locations was conducted. For the purpose of this analysis the Booroola $\times$ Romney ++ group was eliminated. The model fitted included location, dose of PMSG, 'breed prolificacy' level (high and low), ewe age and all two-factor interactions. The importance of the 3-factor interaction location $\times$ breed-prolificacylevel $\times$ dose was also examined. For this analysis the variables examined were ovulation rate after PMSG and the ratio of this trait to ovulation rate after sponge removal.

\section{Results}

The mean ovulation rate after sponge removal is given in Table 2 for each breed and age group along with mean breed liveweights. Breed differences in ovulation rate were significant at all locations $(P<0.001)$ and differences in ovulation rate amongst age classes were significant for all breed groups in Ireland and New Zealand $(P<0.05)$. For the two Moroccan breeds, however, ovulation rate increased substantially with age in the D'Man but failed to do so in the Timhadite, resulting in a significant interaction $(P<0.05)$. The less prolific breed was heavier than the prolific breed in Ireland and Morocco $(P<0.001)$. For the New Zealand breeds the mean liveweight of the carrier and non-carrier Booroola $\times$ Romney ewes was similar and both were significantly lighter than the purebred Romney $(P<0.05)$. Ewe liveweight increased significantly with age at all three locations $(P<0.05)$.

The distributions and co-efficients of variation (CVs) for natural ovulation rate are presented in Table 3. Excluding the Timhadite, in which there was little variation, the non-prolific breeds had CVs ranging from 0.35 to $0 \cdot 37$. The prolific breeds all had higher standard deviations, but varied with respect to co-efficients of variation. The Booroola $\times$ Romney $\mathrm{F}+$ ewes had a CV similar to that of the non-prolific breeds while the Finnish Landrace ewes were less variable $(0 \cdot 27)$ and the D'Man ewes more variable $(0 \cdot 50)$.

The least-squares means for ovulation rate after administration of the various dosages of PMSG are given in Table 4 as the antilog of the estimates. The analysis of variance showed that breed and dose of PMSG effects on ovulation rate were highly significant $(P<0.001)$ at all locations but ewe age tended to be unimportant although 1-5-year-old ewes had the lowest ovulation rate for all breeds. The linear and quadratic components of the dose effect were significant at 
Table 2. Mean ovulation rate immediately after sponge removal and liveweight for non-prolific and prolific ewe breeds (least squares means)

\begin{tabular}{lccccc}
\hline & \multicolumn{5}{c}{ Age of ewe (years) } \\
\cline { 2 - 5 } Location and breed & 1.5 & 2.5 & $\geq 3.5$ & All & $\begin{array}{c}\text { Liveweight } \\
(\mathrm{kg})\end{array}$ \\
\hline $\begin{array}{l}\text { Ireland } \\
\quad \text { Galway }\end{array}$ & 1.60 & 1.81 & 1.90 & 1.77 & 73.2 \\
$\quad$ Finnish Landrace & 2.67 & 3.21 & 3.25 & 3.04 & 43.0 \\
$\quad \begin{array}{l}\text { Morocco } \\
\quad \text { Timhadite }\end{array}$ & 1.00 & 1.00 & 1.10 & 1.03 & 36.6 \\
$\quad$ D'Man & 1.85 & 2.18 & 2.85 & 2.29 & 29.1 \\
$\quad$ New Zealand & & & & & \\
$\quad$ Romney & 1.48 & 1.50 & 1.61 & 1.53 & 52.3 \\
$\quad$ Booroola $\times$ Romney $(++)$ & 1.41 & 1.74 & 1.80 & 1.65 & 49.7 \\
$\quad$ Booroola $\times$ Romney $(\mathrm{F}+)$ & 3.11 & 4.20 & 3.43 & 3.58 & 49.7 \\
\hline
\end{tabular}

Table 3. Distribution of natural ovulation rate in prolific and non-prolific ewe breeds

\begin{tabular}{|c|c|c|c|c|c|c|c|c|c|}
\hline \multirow[b]{2}{*}{ Location and breed } & \multirow[b]{2}{*}{$\mathrm{CV}$} & \multicolumn{8}{|c|}{ Number of corpora lutea } \\
\hline & & 1 & 2 & 3 & 4 & 5 & 6 & 7 & 10 \\
\hline \multicolumn{10}{|l|}{ Ireland } \\
\hline Galway & 0.35 & 19 & 34 & 6 & 0 & 0 & 0 & 0 & 0 \\
\hline Finnish Landrace & 0.27 & 1 & 13 & 31 & 12 & 3 & 0 & 0 & 0 \\
\hline \multicolumn{10}{|l|}{ Morocco } \\
\hline Timhadite & $0 \cdot 18$ & 57 & 2 & 0 & 0 & 0 & 0 & 0 & 0 \\
\hline D’Man & 0.50 & 16 & 22 & 10 & 9 & 0 & 1 & 0 & 0 \\
\hline \multicolumn{10}{|l|}{ New Zealand } \\
\hline Romney & 0.37 & 30 & 26 & 2 & 0 & 0 & 0 & 0 & 0 \\
\hline Booroola $\times$ Romney $(++)$ & 0.37 & 23 & 33 & 1 & 1 & 0 & 0 & 0 & 0 \\
\hline Booroola $\times$ Romney $(\mathrm{F}+)$ & 0.41 & 2 & 8 & 22 & 16 & 6 & 1 & 2 & 1 \\
\hline
\end{tabular}

Table 4. Least-squares means (as antilog of the estimates ( \pm s.e. $)^{*}$ ) for ovulation rate after treatment with different doses of PMSG

\begin{tabular}{lcccr}
\hline & \multicolumn{4}{c}{ Dose of PMSG (i.u.) } \\
\cline { 2 - 5 } Location and breed & 0 & 375 & 750 & \multicolumn{1}{c}{1500} \\
\hline $\begin{array}{l}\text { Ireland } \\
\quad \text { Galway }\end{array}$ & $1.38 \pm 0.1$ & $1.43 \pm 0.2$ & $1.77 \pm 0.3$ & $4.05 \pm 0.7$ \\
$\quad$ Finnish Landrace & $2.87 \pm 0.1$ & $3.53 \pm 0.5$ & $5.01 \pm 0.9$ & $10.36 \pm 1.6$ \\
$\quad$ Morocco & & & & \\
$\quad$ Timhadite & $1.02 \pm 0.0$ & $1.57 \pm 0.2$ & $4.58 \pm 1.1$ & $6.93 \pm 1.0$ \\
$\quad$ D'Man & $1.56 \pm 0.2$ & $2.40 \pm 0.4$ & $6.72 \pm 1.2$ & $11.01 \pm 1.3$ \\
New Zealand & & & & \\
$\quad$ Romney & $1.26 \pm 0.1$ & $1.23 \pm 0.2$ & $1.91 \pm 0.4$ & $4.76 \pm 0.7$ \\
$\quad$ Booroola $\times$ Romney (++) & $1.50 \pm 0.2$ & $1.52 \pm 0.1$ & $2.24 \pm 0.4$ & $6.53 \pm 1.7$ \\
$\quad$ Booroola $\times$ Romney (F+) & $2.75 \pm 0.2$ & $3.62 \pm 0.2$ & $6.11 \pm 1.1$ & $9.39 \pm 1.9$ \\
\hline
\end{tabular}

*Approximate s.e. calculated within each subclass using untransformed data. 
Table 5. Ratio of ovulation rate following PMSG to ovulation rate observed at the cycle before PMSG administration

\begin{tabular}{lccccc}
\hline & \multicolumn{5}{c}{ Dose of PMSG (i.u.) } \\
\cline { 2 - 4 } Location and breed & 0 & 375 & 750 & 1500 & $\begin{array}{c}\text { Approx. } \\
\text { s.e. }\end{array}$ \\
\hline Ireland & & & & & \\
$\quad$ Galway & 0.79 & 1.05 & 1.24 & 3.14 & 0.38 \\
$\quad$ Finnish Landrace & 0.94 & 1.30 & 2.51 & 4.23 & \\
$\quad \begin{array}{l}\text { Morocco } \\
\quad \text { Timhadite }\end{array}$ & 1.06 & 1.73 & 6.03 & 7.63 & 0.60 \\
$\quad$ D'Man & 1.07 & 1.38 & 3.90 & 4.98 & \\
$\quad$ New Zealand & & & & & \\
$\quad$ Romney & 1.07 & 1.00 & 1.49 & 4.15 & 0.44 \\
$\quad$ Booroola $\times$ Romney (++) & 0.92 & 1.20 & 1.80 & 5.79 & \\
$\quad$ Booroola $\times$ Romney (F+) & 0.98 & 1.16 & 2.01 & 3.45 & \\
\hline
\end{tabular}

Table 6. Effect of ewe breed and PMSG on fertility (\% ewes lambing to the oestrus after PMSG)

\begin{tabular}{|c|c|c|c|c|}
\hline \multirow[b]{2}{*}{ Location and breed } & \multicolumn{4}{|c|}{ Dose of PMSG (i.u.) } \\
\hline & 0 & 375 & 750 & 1500 \\
\hline \multicolumn{5}{|l|}{ Ireland } \\
\hline Galway & $73 \cdot 3$ & $45 \cdot 6$ & $93 \cdot 4$ & $52 \cdot 4$ \\
\hline Finnish Landrace & $82 \cdot 5$ & $95 \cdot 1$ & $66 \cdot 0$ & 64.9 \\
\hline \multicolumn{5}{|l|}{ New Zealand } \\
\hline Romney & $86 \cdot 7$ & $71 \cdot 4$ & $73 \cdot 3$ & $50 \cdot 0$ \\
\hline Booroola $\times$ Romney $(++)$ & $71 \cdot 7$ & $86 \cdot 7$ & $86 \cdot 7$ & 43.9 \\
\hline Booroola $\times$ Romney $(\mathrm{F}+)$ & $85 \cdot 1$ & $53 \cdot 3$ & $53 \cdot 3$ & $41 \cdot 9$ \\
\hline
\end{tabular}

all locations. The only evidence for a cubic component was in Morocco $(P<0.01)$. The only significant two factor interaction was for age $\times$ dose in the Irish data set $(P<0.05)$.

Both the natural and induced ovulation rates were essentially unrelated to ewe bodyweight in all locations. The pooled within-breed correlation coefficients between natural ovulation rate and liveweight were $0 \cdot 08,0 \cdot 14$ and $0 \cdot 11$ in Ireland, Morocco and New Zealand respectively. The corresponding coefficients for the induced ovulation rates were $-0.14,-0.02$ and -0.07 , respectively. The pooled correlation between natural and induced ovulation rate (log scale) was $0.15(P<0.01)$.

The combined analysis of ovulation rate (log scale) after PMSG administration revealed significant interactions for location by dose of PMSG $(P<0.001)$ and location by 'breed prolificacy' $(P<0.001)$. The overall effects of ewe age, 'breed prolificacy' and dose of PMSG were highly significant and there was no evidence for any location $\times$ 'breed prolificacy' $\times$ dose interaction. When the response to PMSG was expressed as the ratio of ovulation rate following PMSG to ovulation rate after sponge removal the interactions location $\times$ dose of PMSG and location $\times$ 'breed prolificacy' remained significant as did the effect of PMSG dose. However, the overall 'breed prolificacy' effect was no longer significant which, as can be seen from the means in Table 5, results from the low prolificacy breed having the greatest relative response in Morocco $(P<0.01)$ with the reverse pattern being observed in Ireland $(P<0.02)$ while breed had no effect on the ratio in the New Zealand data $(P>0 \cdot 5)$. The response (measured as a ratio) was significantly higher in Morocco when compared with the other locations.

The effects of ewe breed and PMSG dose on fertility and litter size (per ewe lambing) in Ireland and New Zealand are shown in Tables 6 and 7. The effects of ewe breed and PMSG dose were 
Table 7. Effect of ewe breed and PMSG dose on litter size (lambs born per ewe lambing)

\begin{tabular}{lcccc}
\hline & \multicolumn{4}{c}{ Dose of PMSG (i.u.) } \\
\cline { 2 - 5 } Location and breed & 0 & 375 & 750 & 1500 \\
\hline Ireland & & & & \\
$\quad$ Galway & 1.44 & 1.69 & 1.66 & 2.43 \\
$\quad$ Finnish Landrace & 2.15 & 2.54 & 2.19 & 1.47 \\
$\quad$ New Zealand & & & & \\
$\quad$ Romney & 1.22 & 1.00 & 2.21 & 2.54 \\
$\quad$ Booroola $\times$ Romney (++) & 1.35 & 1.61 & 2.22 & 2.23 \\
$\quad$ Booroola $\times$ Romney (F+) & 2.68 & 2.73 & 3.58 & 2.80 \\
\hline
\end{tabular}

significant $(P<0.01)$ in the New Zealand data set but not in Ireland. There was, however, a significant breed $\times$ dose interaction for both traits in the Irish data set $(P<0.05)$ and these were the only significant interactions detected. It is clear from Table 6 that 1500 i.u. PMSG depressed fertility for all breeds at both locations. For the prolific ewe breeds, increasing PMSG dose from 750 to $1500 \mathrm{i}$.u. led to a reduction in the number of lambs born per ewe lambing.

The data in relation to plasma progesterone after PMSG administration showed a significant $(P<0.01)$ linear increase with dose of PMSG for all breeds studied in Ireland and New Zealand. In both data sets the correlation coefficients between ovulation rate and progesterone concentration was significant, 0.71 and 0.65 in Ireland and New Zealand, respectively.

\section{Discussion}

In all 3 trials animals of the prolific genotype had a greater ovulation rate after PMSG than did the non-prolific controls, confirming results of other experiments (Bindon et al., 1971; Bradford et al., 1971; Trounson \& Moore, 1972; Bindon \& Piper, 1982) showing greater gonadotrophic responsiveness in animals with higher natural ovulation rates. The higher response observed in Booroola $x$ Romney $\mathrm{F}+$ ewes than in non-carrier ewes confirms previous reports that the Booroola F-gene enhances responsiveness to PMSG (Piper et al., 1982; Kelly et al., 1983). In this study the pattern of response to PMSG in the three prolific breeds (Finnish Landrace, D'Man and the F+ Booroola $x$ Romney) was similar and all had means of about 10 ovulations in response to $1500 \mathrm{i} . u$. of the same batch of PMSG. Therefore, although the genetic basis of their high prolificacy differs, these three types of sheep are similar in this aspect of their physiology.

For the non-prolific breeds, the pattern of response in the Timhadite ewes differed markedly from that observed for the Galway and Romney breeds. This interpretation is supported by the significant interactions for location by prolificacy level and location by dose. The difference between prolific and non-prolific breeds in Ireland and New Zealand with respect to the pattern of response to increasing dosages of PMSG was similar to that reported for the Merino and Romney lines of sheep selected for multiple births (Bindon et al., 1971; Smith, 1976).

Merino ewes selected against prolificacy ('O' line; Bindon et al., 1971) responded similarly to the Galways and Romneys in this study. The non-carrier Booroola Merino $\times$ Romney cross ewes in this study were more responsive than contemporary Romneys, suggesting that the background genotype of the Booroola Merino strain may be contributing some responsiveness independent of the effects of the major (F) gene (Piper et al., 1982; Kelly et al., 1983).

An interesting aspect of the overall analysis was the absence of a difference between prolific and non-prolific breed types when the response to PMSG was expressed relative to natural ovulation rate. However, there was a significant interaction between prolificacy and location attributable 
largely to the high relative response shown by the low prolificacy breed in Morocco contrasted with the lower response of this breed type in Ireland. The removal of the association between 'breed prolificacy' and response to PMSG by this simple transformation needs to be considered in the interpretation of the generally observed differences between prolific and non-prolific ewe breeds in ovarian responsiveness to exogenous gonadotrophins. The present results suggest that response to PMSG is a multiplicative function of natural ovulation rate. This interpretation is supported by the observation that significant ewe age effects on ovulation rate following PMSG $(P<0.01$ in overall analysis) were completely removed $(P<0.9)$ when the response to PMSG was expressed as a multiple of natural ovulation rate.

The reduction in fertility at the highest level of PMSG was not surprising in view of the high mean ovulation rates achieved and the fact that embryo survival declines steadily as the number of eggs shed increases (Hanrahan, 1982), plus the likely associated effects of ovarian overstimulation on the hormonal milieu in the periovulatory period (Evans \& Robinson, 1980). A positive association between litter size and dose of PMSG was evident in the low prolificacy breeds (Galway, Rommey and Booroola $\times$ Romney ++ ) which is consistent with the results reported by Allison (1975) for Romney ewes. The absence of such an association in the high prolificacy breeds (Finnish Landrace and Booroola $\times$ Romney) is probably attributable to the high ovulation rates in those breeds in the absence of PMSG treatment and that treatment with PMSG yielded ovulation rates well in excess of uterine capacity.

\section{References}

Allison, A.J.A. (1975) Effect of nutritionally induced liveweight differences on the ovarian response and fertility in ewes treated with Pregnant Mares' Serum Gonadotrophin. N.Z.Jl agric. Res. 18, 101-107.

Bindon, B.M. \& Piper, L.R. (1982) Physiological basis of the ovarian response to PMSG in sheep and cattle. In Embryo Transfer in Cattle, Sheep and Goats, pp. 1-5. Eds J. N. Shelton, A. O. Trounson, N. W. Moore \& J. W. James. Union Offset Company, Australian Capital Territory.

Bindon, B.M., Ch'ang, T.S. \& Turner, H.N. (1971) Ovarian response to gonadotrophin by Merino ewes selected for fecundity. Aust. J. agric. Res. 22, 809-820.

Bindon, B.M., Blanc, M.R., Pelletier, J., Terqui, M. \& Thimonier, J. (1979) Peri-ovulatory gonadotrophin and ovarian steroid patterns in sheep of breeds with differing fecundity. J. Reprod. Fert. 55, 15-25.

Bindon, B.M., Piper, L.R. \& Thimonier, J. (1984) Preovulatory $\mathbf{L H}$ characteristics and time of ovulation in the prolific Booroola Merino ewe. J. Reprod. Fert. 71, 519-523.

Bindon, B.M., Piper, L.R., Cummins, L.J., O'Shea, T., Hillard, M.A., Findlay, J.K. \& Robertson, D.E. (1985) Reproductive endocrinology of prolific sheep: studies of the Booroola Merino. In Genetics of Reproduction in Sheep, pp. 217-235. Eds R. B. Land \& D. W. Robinson. Butterworths, London.

Bradford, G.E., Quirke, J.F. \& Hart, R. (1971) Natural and induced ovulation rate in Finnish Landrace and other breeds of sheep. Anim. Prod. 13, 627-635.

Cahill, L.P., Saumande, J., Ravault, J.P., Blanc, M., Thimonier, J., Mariana, J. \& Mauleon, P. (1981) Hormonal and follicular relationships in ewes of high and low ovulation rates. J. Reprod. Fert. 62, 141-150.
Davis, G.H., Montgomery, G.W., Allison, A.J., Kelly, R.W. \& Bray, A.R. (1982) Segregation of a major gene influencing fecundity in progeny of Booroola sheep. Nr.Z.Jl agric. Res. 25, 525-529.

Evans, G. \& Robinson, T.J. (1980) The control of fertility in sheep: endocrine and ovarian responses to progestagen-PMSG treatment in the breeding season and in a noestrus. J. agric. Sci., Camb. 94, 69-88.

Hanrahan, J.P. (1982) Selection for increased ovulation rate, litter size and embryo survival. Proc. 2nd World Congr. Genetics Applied to Livestock Prod., Madrid, $\mathrm{V}, 294-309$.

Hanrahan, J.P. \& Quirke, J.F. (1982) Selection on ovulation rate in sheep aided by the use of superovulation and egg transfer. In Proc. Wld Congr. Sheep and Beef Cattle Breeding, Palmerston North, Vol. II, pp. 329335. Eds R. A. Barton \& W. C. Smith. Dunmore Press Ltd, Palmerston North.

Kelly, R.W., Owens, J.L., Crosbie, S.F., McNatty, K.P. \& Hudson, N. (1983) Influence of Booroola Merino genotype on the responsiveness of ewes to Pregnant Mares' Serum Gonadotrophin, Iuteal weights and peripheral progesterone concentration Anim. Reprod. Sci. 6, 199-207.

Lahlou-Kassi, A., Schams, D. \& Glatzel, P. (1984) Plasma gonadotrophin concentrations during the oestrous cycle and after ovariectomy in two breeds of sheep with low and high fecundity, J. Reprod. Fert. 70, $165-173$.

Land, R.B., Pelletier, J., Thimonier, J. \& Mauleon, P. (1973) A quantitative study of genetic differences in the incidence of oestrus, ovulation and plasma luteinizing hormone concentration in the sheep. $J$. Endocr. 58, 305-317.

Munro, C. \& Stabenfeldt, G.H. (1984) Development of a 
microtiter plate enzyme immunoassay for the determination of progesterone. J. Endocr. 101, 41-49.

Piper, L.R. \& Bindon, B.M (1982) The Booroola Merino and the performance of medium non-peppin crosses at Armidale. In The Booroola Merino, pp. 9-20. Eds L. R. Piper, B. M. Bindon \& R. D. Nethery. CSIRO, Melbourne.

Piper, L.R., Bindon, B.M., Curtis, Y.M., Cheers, M.A. \& Nethery, R.D. (1982) Response to PMSG in Merino and Booroola Merino crosses. Proc. Aust. Soc. Reprod. Biol. 14, 82, Abstr.
Quirke, J.F., Hanrahan, J.P. \& Gosling, J.P. (1979) Plasma progesterone levels throughout the oestrous cycle and release of $\mathrm{LH}$ at oestrus in sheep with different ovulation rates. J. Reprod. Fert. 55, 37-44.

Smith, J.F. (1976) Selection for fertility and response to PMSG in Romney ewes. Proc. N.Z. Soc. Anim. Prod. 36, 247-251.

Trounson, A. \& Moore, N.W. (1972) Ovulation rate and survival of fertilized ova in Merino ewes selected for and against multiple births. Aust. J. agric. Res. 23, $851-858$.

Received 10 November 1986 